\title{
An additional genus and two additional species of Forticulcitinae (Digenea: Haploporidae)
}

\author{
Michael J. Andres ${ }^{1}$, Stephen S. Curran ${ }^{1}$, Thomas J. Fayton ${ }^{1}$, Eric E. Pulis ${ }^{2}$ and Robin M. Overstreet
}

${ }^{1}$ Department of Coastal Sciences, University of Southern Mississippi, Ocean Springs, Mississippi, USA;

${ }^{2}$ The Institute for Marine Mammal Studies, Gulfport, Mississippi, USA

\begin{abstract}
Forticulcita platana sp. n. and Forticulcita apiensis sp. n. are described from Mugil liza Valenciennes in Argentina, and from Mugil cephalus Linnaeus in Salt Springs, Florida, USA, respectively. Supplemental material relating to the hermaphroditic sac of Forticulcita gibsoni Blasco-Costa, Montero, Balbuena, Raga et Kostadinova, 2009 is provided from a specimen isolated from $M$. cephalus off Crete, Greece. Forticulcita platana can be distinguished from all species of Forticulcita Overstreet, 1982 except F. gibsoni, based on possessing small pads or gland cells along the hermaphroditic duct. It can be differentiated from that species in possessing a hermaphroditic sac that is one and a half to two times longer than wide rather than one that is approximately three times longer than wide, longer eggs (44-52 $\mu \mathrm{m}$ rather than 34-44 $\mu \mathrm{m}$ long) and a shorter post-testicular space ( $<45 \%$ of the body length). Forticulcita apiensis can be differentiated from the other species of Forticulcita in possessing a testis that is shorter than or equal to the pharynx rather than one that is longer than the pharynx. Xiha gen. n. is erected for Dicrogaster fastigatus Thatcher et Sparks, 1958 as Xiha fastigata (Thatcher et Sparks, 1958) comb. n., and we tentatively consider Dicrogaster fragilis Fernández Bargiela, 1987 to be Xiha fragilis (Fernández Bargiela, 1987) comb. n. The new genus fits within the concept of Forticulcitinae Blasco-Costa, Balbuena, Kostadinova et Olson, 2009 in having a vitellarium comprised of a single elongate to subspherical mass. Xiha can be differentiated from Forticulcita in having spines lining the hermaphroditic duct, or intromittent organ. A Bayesian inference analysis of partial 28S rDNA sequences of the two New World species of Forticulcita, Xiha fastigata and previously published haploporids places Xiha fastigata within the Forticulcitinae and sister to Forticulcita. Amended diagnoses for the subfamily and for Dicrogaster Looss, 1902 are provided.
\end{abstract}

Keywords: 28S rDNA, Dicrogaster, Digenea, Haploporinae, molecular phylogeny, mullet, Mugil, Mugilidae

Overstreet (1982) erected Forticulcita Overstreet, 1982 for Forticulcita glabra Overstreet, 1982 from the bluespot mullet, Moolgarda seheli (Forsskål) (as Valamugil seheli [Forsskål]), off Eilat, Israel, in the Red Sea. He considered $F$. glabra to be closest to members of Haploporus Looss, 1902 rather than to Dicrogaster Looss, 1902 because members of Dicrogaster have an armed hermaphroditic duct and 'characteristically stubby' caeca relative to those of F. glabra. Hassanine (2007) described a second species, Forticulcita mugilis Hassanine, 2007 from Crenimugil crenilabis (Forsskål) also in the Red Sea off Sharm El-Sheikh, South Sinai, Egypt. Blasco-Costa et al. (2009a) described Forticulcita gibsoni Blasco-Costa, Montero, Balbuena, Raga et Kostadinova, 2009 from Mugil cephalus Linnaeus off Santa Pola, Spain. Blasco-Costa et al. (2009b) established the Forticulcitinae Blasco-Costa, Balbuena, Kostadinova et Olson, 2009 based on the presence of a 'well-delimited eversible intromittent copulatory organ' or 'ejaculatory organ', vitellarium a single spherical to subtriangular compact mass, and a Bayesian inference (BI) hypothesis of the partial 28S rDNA that resolved F. gibsoni outside of the Haploporinae Nicoll, 1914.
Dicrogaster fastigata Thatcher et Sparks, 1958 has been the only accepted non-forticulcitine haploporid with a vitellarium comprised of a single elongate to subspherical mass of follicles. Yamaguti (1958) erected the Dicrogasterinae Yamaguti, 1958 for the members of Dicrogaster. He considered the key character of the subfamily to be the single median vitellarium. Overstreet (1982) did not accept the Dicrogasterinae (that action was corroborated in the molecular hypothesis by Blasco-Costa et al. [2009b]) because the type-species, Dicrogaster perpusilla Looss, 1902 and Dicrogaster contracta Looss, 1902 were both described as possessing a vitellarium comprising two close subspherical masses. Fernández Bargiela (1987) described another species with a single vitellarium, Dicrogaster fragilis Fernández Bargiela, 1987 from M. cephalus off Chile. Blasco-Costa et al. (2009a) revised Dicrogaster, considered $D$. fragilis to be a junior synonym of $D$. fastigata and accepted only $D$. perpusilla, $D$. contracta and $D$. fastigata. In this study, we provide the description of two New World species of Forticulcita, provide supplemental material relating to the hermaphroditic duct of $F$. gibsoni, erect a new 
Table 1. Sequences from GenBank used for phylogenetic analysis in the present study.

\begin{tabular}{|c|c|c|c|c|}
\hline Family & Species & Host & GenBank & Reference \\
\hline \multicolumn{2}{|c|}{ Atractotrematidae Atractotrema sigani Durio et Manter,1969 } & Siganus lineatus (Valenciennes) & AY222267 & Olson et al. (2003) \\
\hline & $\begin{array}{l}\text { Pseudomegasolena ishigakiense Machida et } \\
\text { Kamiya, } 1976\end{array}$ & Scarus rivulatus Valenciennes & AY222266 & Olson et al. (2003) \\
\hline \multirow[t]{2}{*}{ 'Cadenatellinae' } & Cadenatella isuzumi Machida, 1993 & $\begin{array}{l}\text { Kyphosus vaigiensis } \\
\text { Quoy et Gaimard }\end{array}$ & FJ788497 & Bray et al. (2009) \\
\hline & Cadenatella pacifica (Yamaguti, 1970) & Kyphosus vaigiensis & FJ788498 & Bray et al. (2009) \\
\hline \multirow[t]{22}{*}{ Haploporidae } & Capitimitta costata Pulis et Overstreet, 2013 & $\begin{array}{l}\text { Selenotoca multifasciata } \\
\text { (Richardson) }\end{array}$ & KC206497 & Pulis and Overstreet (2013) \\
\hline & Capitimitta darwinensis Pulis et Overstreet, 2013 & Selenotoca multifasciata & KC206498 & Pulis and Overstreet (2013) \\
\hline & Capitimitta sp. & Selenotoca multifasciata & KC206499 & Pulis and Overstreet (2013) \\
\hline & Dicrogaster contracta Looss, 1902 & Liza aurata (Risso) & FJ211261 & Blasco-Costa et al. (2009b) \\
\hline & Dicrogaster perpusilla Looss, 1902 & Liza ramada (Risso) & FJ211238 & Blasco-Costa et al. (2009b) \\
\hline & $\begin{array}{l}\text { Forticulcita gibsoni Blasco-Costa, Montero, } \\
\text { Balbuena, Raga et Kostadinova, } 2009\end{array}$ & Mugil cephalus Linnaeus & FJ211239 & Blasco-Costa et al. (2009b) \\
\hline & Haploporus benedeni (Stossich, 1887) & Liza ramada & FJ211237 & Blasco-Costa et al. (2009b) \\
\hline & Hapladena nasonis Yamaguti, 1970 & Naso unicornis (Forsskål) & AY222265 & Olson et al. (2003) \\
\hline & Intromugil alachuaensis (Shireman, 1964) & Mugil cephalus & KC430095 & Pulis et al. (2013) \\
\hline & $\begin{array}{l}\text { Intromugil mugilicolus Pulis, Fayton, Curran } \\
\text { et Overstreet, } 2013\end{array}$ & Mugil cephalus & KC430096 & Pulis et al. (2013) \\
\hline & Lecithobotrys putrescens Looss, 1902 & Liza saliens (Risso) & FJ211236 & Blasco-Costa et al. (2009b) \\
\hline & Litosaccus brisbanensis (Martin, 1974) & Mugil cephalus & KM253765 & Andres et al. (2014) \\
\hline & $\begin{array}{l}\text { Parasaccocoelium haematocheilum Besprozvannykh, } \\
\text { Atopkin, Ermolenko et Nikitenko, } 2015\end{array}$ & $\begin{array}{l}\text { Liza haematocheila } \\
\text { (Temminck et Schlegel) }\end{array}$ & HF548461 & Besprozvannykh et al. (2015) \\
\hline & Parasaccocoelium mugili Zhukov, 1971 & Liza haematocheila & HF548468 & Besprozvannykh et al. (2015) \\
\hline & $\begin{array}{l}\text { Parasaccocoelium polyovum Besprozvannykh, } \\
\text { Atopkin, Ermolenko et Nikitenko, } 2014\end{array}$ & $\begin{array}{l}\text { Liza haematocheila } \\
\text { (Temminck et Schlegel) }\end{array}$ & HF548474 & Besprozvannykh et al. (2015) \\
\hline & $\begin{array}{l}\text { Ragaia lizae Blasco-Costa, Montero, Gibson, } \\
\text { Balbuena et Kostadinova, } 2009\end{array}$ & Liza aurata & FJ211235 & Blasco-Costa et al. (2009b) \\
\hline & $\begin{array}{l}\text { Saccocoelium brayi Blasco-Costa, Balbuena, Raga, } \\
\text { Kostadinova et Olson, } 2010\end{array}$ & Liza saliens & FJ211234 & Blasco-Costa et al. (2009b) \\
\hline & $\begin{array}{l}\text { Saccocoelium cephali Blasco-Costa, Montero, } \\
\text { Gibson, Balbuena, Raga et Kostadinova, } 2009\end{array}$ & Mugil cephalus & FJ211233 & Blasco-Costa et al. (2009b) \\
\hline & Saccocoelium obesum Looss, 1902 & Liza ramada & FJ211259 & Blasco-Costa et al. (2009b) \\
\hline & Saccocoelium tensum Looss, 1902 & Liza aurata & FJ211258 & Blasco-Costa et al. (2009b) \\
\hline & Saccocoelioides sp. & Poeciliidae Garman & EF032696 & Curran et al. (2006) \\
\hline & Spiritestis herveyensis Pulis et Overstreet, 2013 & Moolgarda seheli (Forsskål) & KC206500 & Pulis and Overstreet (2013) \\
\hline
\end{tabular}

genus to accept $D$. fastigata, and provide a BI analysis based on partial 28S rDNA that estimates the affinity of those species with 26 previously published haploporoids.

\section{MATERIALS AND METHODS}

Specimens of Mugil cephalus were collected from Grand Isle, Louisiana, USA, in June 2013 and Davis Bayou, Ocean Springs, Mississippi, USA, in March 2010 using a cast-net and from Salt Spring, Florida, USA, in March 2013 by Hawaiian sling. Specimens of Mugil liza Valenciennes were collected from Rio de la Plata, Punta Lara, and Rio Salado, Cerro de la Gloria, both in Provincia de Bueno Aires, Argentina, in March 2008 using a castnet. A single M. cephalus was collected off Chania, Crete, Greece, in September 2005 by baited dip-net. Trematodes were collected following the procedure outlined by Cribb and Bray (2010) for gastrointestinal species, skipping the initial examination under a dissecting scope because of the high volume of the intestinal contents.

Worms were rinsed and cleaned in a container with saline and examined briefly. Subsequently, most of the saline was removed from the container, and the worms were killed by pouring nearboiling water over them (with the exception of a single worm collected from Chania that was fixed under coverslip pressure with a lighter and preserved in $10 \%$ buffered formalin) and then preserved in $70 \%$ ethanol or $10 \%$ buffered formalin. Worms were stained in Van Cleave's haematoxylin or Mayer's haematoxylin, dehydrated in a graded ethanol series, cleared in clove oil (Van Cleave's) or methyl salicylate (Mayer's), and mounted permanently in Canada balsam (Van Cleave's) or dammar gum (Mayer's).

Measurements were made using a compound microscope equipped with a differential interference contrast, a Canon EOS Rebel T1i camera, and calibrated digital software (iSolutions Lite $^{\odot}$ ). All measurements are in micrometres; data for the holotype are followed by the range of data for the other specimens in parentheses. Terminology pertaining to the hermaphroditic sac and its structures follows the terminology by Pulis and Overstreet (2013). The museum collection abbreviations are used as follows: BMNH - British Museum of Natural History, London, England; MACN-Pa - Museo Argentino de Ciencias Naturales National Collection of Parasitology, Buenos Aires, Argentina; USNM - Smithsonian National Museum of Natural History, Washington, DC, USA; and USNPC - United States National Parasite Collection (previously in Beltsville, Maryland, USA).

Genomic DNA was isolated using Qiagen DNAeasy Blood and Tissue Kit (Qiagen, Inc., Valencia, California, USA) following the instructions provided; genomic DNA was eluted with 200 $\mu l$ of elution buffer. DNA fragments ca 2550 base pairs (bp) long, comprising the $3^{\prime}$ end of the $18 \mathrm{~S}$ nuclear rDNA gene, internal transcribed spacer region (including ITS1 $+5.8 \mathrm{~S}+\mathrm{ITS} 2$ ), and 


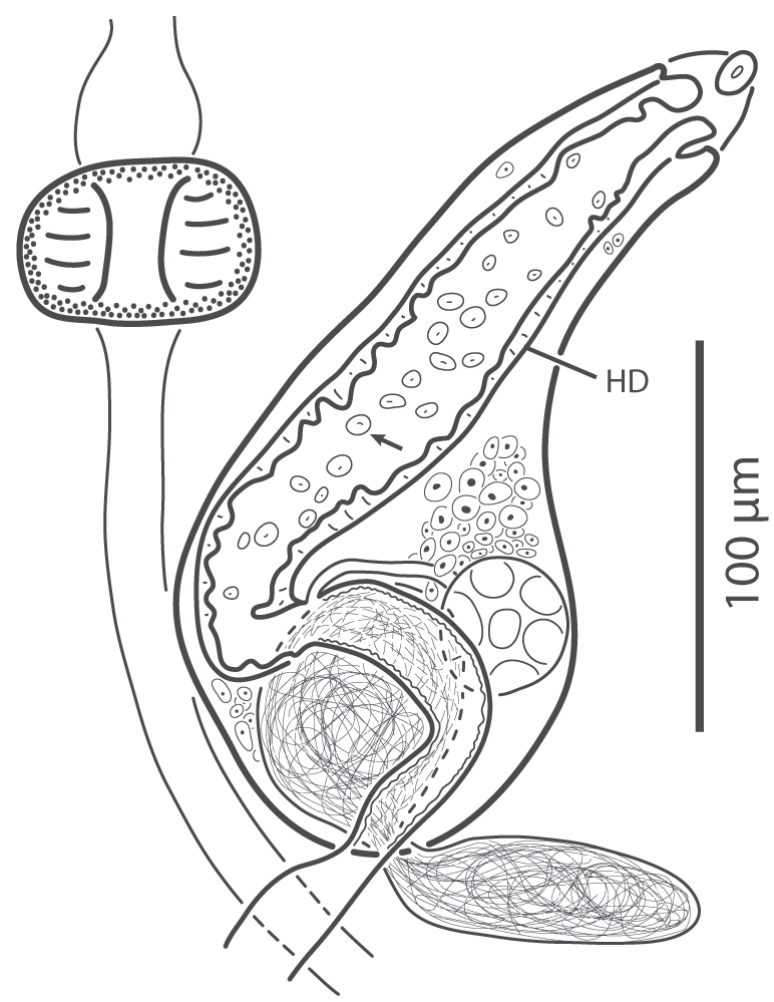

Fig. 1. Hermaphroditic sac of flattened specimen of Forticulcita gibsoni Blasco-Costa, Montero, Balbuena, Raga et Kostadinova, 2009 from Mugil cephalus - displaying pads or gland cells (indicated by arrow) lining hermaphroditic duct (HD).

the $5^{\prime}$ end of the $28 \mathrm{~S}$ gene (including variable domains D1-D3), were amplified from the extracted DNA by polymerase chain reaction (PCR) on a PTC-200 Peltier Thermal Cycler using forward primer ITSF (5'-CGCCCGTCGCTACTACCGATTG-3') and reverse primer 1500R (5'-GCTATCCTGAGGGAAACTTCG-3'). These PCR primers and multiple internal primers were used in sequencing reactions. The internal forward primers were DIGL2 (5'-AAGCATATCACTAAGCGG-3'), 300F (5'-CAAGTACCGTGAGGGAAAGTTG-3'), and 900F (5'-CCGTCTTGAAACACGGACCAAG-3'), and the internal reverse primers were 300R (5'-CAACTTTCCCTCACGGTACTTG-3'), DIGL2R (5'-CCGCTTAGTGATATGCTT-3'), and ECD2 (5'-CTTGGTCCGTGTTTCAAGACGGG-3'). The resulting PCR products following the protocols of Tkach et al. (2003) were excised from PCR gel using QIAquick Gel Extraction Kit (Qiagen, Inc.) following the kit instructions, cycle-sequenced using $\mathrm{ABI} \mathrm{BigDye}^{\mathrm{TM}}$ chemistry (Applied Biosystems, Inc., Carlsbad, California, USA), ethanol-precipitated and run on an ABI 3130 Genetic Analyzer ${ }^{\mathrm{TM}}$. Contiguous sequences were assembled using Sequencher ${ }^{\mathrm{TM}}$ (GeneCodes Corp., Ann Arbor, Michigan, USA, Version 5.0) and representative sequences submitted to GenBank. Previously published 28S ribosomal RNA gene sequences of species of Haploporidae were used for comparison (see Table 1 for accession numbers and host information) with newly submitted sequences. The sequences were aligned using MAFFT version $6.611 \mathrm{~b}$ (Katoh et al. 2005) with 1000 cycles of iterative refinement and the genafpair algorithm. The alignment was masked with ZORRO (Wu et al. 2012) using default settings, positions with confidence scores $<0.4$ were excluded and the alignment was trimmed to the shortest sequence on both 5' and 3' ends in BioEdit, ver. 7.1.3.0. (Hall 1999). Phylogenetic analysis of the data was performed using BI with MrBayes 3.1.2 software (Huelsenbeck and Ronquist 2001). The best nucleotide substitution model was estimated with jModeltest-2 (Guideon and Gascuel 2003, Darriba et al. 2012) as general time reversible with estimates of invariant sites and gamma-distributed among site-rate variation $(\mathrm{GTR}+\mathrm{I}+\Gamma)$. The following model parameters were used in MrBayes: $n s t=6$, rates $=$ invgamma, ngen $=1,000,000$ and samplefreq $=100$. Burnin value was 1,500 estimated by plotting the log-probabilities against generation and visualising plateau in parameter values (sump burnin $=1,500$ ), and nodal support was estimated by posterior probabilities (sumt) (Huelsenbeck et al. 2001) with all other settings left as default.

\section{RESULTS}

Forticulcita gibsoni Blasco-Costa, Montero, Balbuena, Raga et Kostadinova, 2009 Fig. 1

Type and only host: Mugil cephalus Linnaeus, flathead grey mullet, Mugilidae.

Type locality: Off Santa Pola, Spain $\left(38^{\circ} 00^{\prime}-38^{\circ} 20^{\prime}\right.$ N; $\left.0^{\circ} 10^{\prime}-0^{\circ} 40^{\prime} \mathrm{E}\right)$.

Other 1 ocalities: Ebro Delta, Spain $\left(40^{\circ} 30^{\prime}-40^{\circ} 50^{\prime} \mathrm{N}\right.$; $\left.0^{\circ} 30^{\prime}-1^{\circ} 10^{\prime} \mathrm{E}\right)$; Phalasarna, Crete, Greece $\left(35^{\circ} 30^{\prime} 07^{\prime \prime} \mathrm{N}\right.$; $\left.23^{\circ} 34^{\prime} 37^{\prime \prime} \mathrm{E}\right)$.

Site: Intestine.

Ho lo type: BMNH 2008.10.7.61.

Material examined: Paratypes (12 specimens) BMNH 2008.10.7.62-2008.10.7.76; 1 flattened specimen BMNH 2015.3.24.8.

Supplemental material: Tegumental spines 1-2 long. Pars prostatica vesicular. Hermaphroditic duct lined with pads or gland cells (Fig. 1).

Remarks. The pads or gland cells lining the hermaphroditic duct of $F$. gibsoni were not apparent in the paratypes we examined, nor were they described by Blasco-Costa et al. (2009a). However, based on morphological features and geographic location, we have no reason not to consider our specimen conspecific with $F$. gibsoni. Blasco-Costa et al. (2009a) also reported the hermaphroditic duct as narrow, while the specimen we report on has a duct that is wider. This is likely attributed to our specimen being fixed under coverslip pressure. Additionally, our specimen has a slightly wider posterior portion of the hindbody, longer testis length and wider hermaphroditic sac width that we consider to be artifacts of fixation technique. Because of this, additional measurements are not presented.

\section{Forticulcita platana $\mathrm{sp} . \mathrm{n}$.}

Figs. 2, 3

ZooBank number for species:

urn:lsid:zoobank.org:act:5765D1D6-85C8-

4906-91BE-A6CDD99E4AC3

Description (based on 17 mature measured whole mounts): Body fusiform, 790 (501-790) long, widest at midbody, 188 (131-214) wide, representing 24\% 


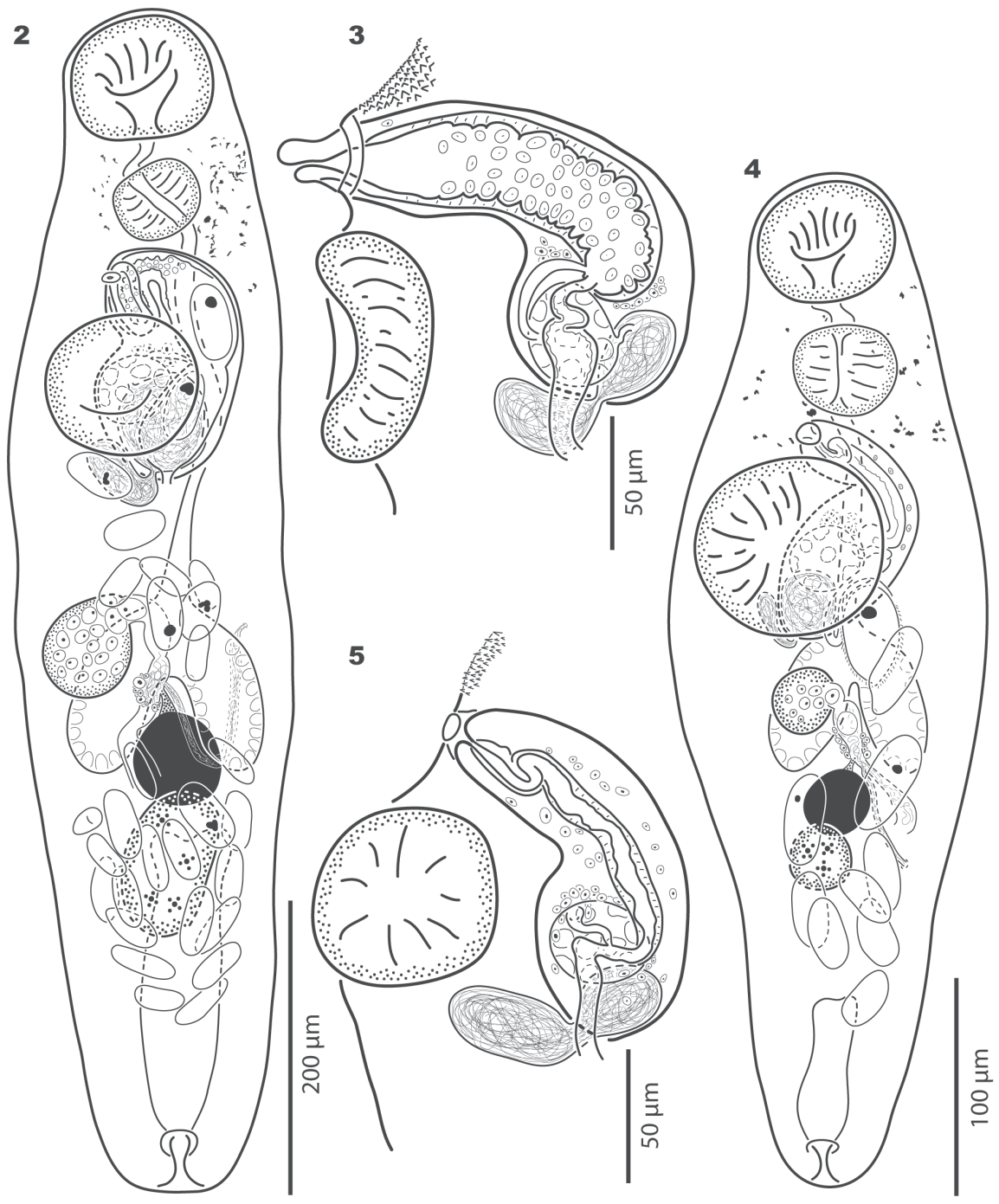

Figs. 2-3. Forticulcita platana sp. n. from Mugil liza. Fig. 2. Ventral view of holotype. Fig. 3. Lateral view of hermaphroditic sac and stubby tegumental spines. Figs. 4-5. Forticulcita apiensis sp. n. Fig. 4. Ventral view of holotype. Fig. 5. Lateral view of hermaphroditic sac and thin tegumental spines.

(24-29\%) of body length (BL). Forebody 197 (154-198) long, representing 25\% (23-31\%) BL. Hindbody 496 (279-496) long, representing 63\% (56-64\%) of BL. Eyespot pigment dispersed in anterior $2 / 3$ of forebody. Tegumental spines stubby, 1-2 long, occurring over entire surface, becoming sparse in posterior $1 / 4$ to $1 / 3$ of body. Oral sucker transversely subspherical, subterminal, 79 (71-81) long, 95 (73-100) wide. Ventral sucker subspherical, 94 (68-97) long, 97 (64-97) wide. Ratio of oral sucker to ventral sucker widths $1: 1.02(0.75-1.02)$. Ratio of oral sucker to ventral sucker lengths $1: 1.19(0.96-1.31)$. Prepharynx 28 (17-33) long. Pharynx transversely subglobular, 47 (39-48) long, 56 (39-60) wide. Ratio of oral sucker width to pharynx width $1: 0.59$ (1: $0.53-0.68$ ). Oesophagus 263 (176-263) long, approximately 4-6 times pharynx length, extending to approximately midbody. Intestinal bifurcation 99 (26-127) posterior to level of ventral sucker. Caeca sac-like, approximately twice as long as wide, vacuolar, terminating blindly 278 (164-369) from posterior end, postcaecal space representing 35\% (33-50\%) of BL.
Testis single, elongate to subspherical, 101 (59-101) long, 52 (42-65) wide, 189 (92-226) from posterior margin of ventral sucker. Post-testicular space 20\% (19-36\%) of BL. External seminal vesicle claviform, 60 (34-63) long, 27 (17-27) wide, dorsal to ventral sucker. Hermaphroditic sac kidney bean-shaped, 154 (120-171) long, 92 (68-98) wide, representing 19\% (19-24\%) of BL, containing terminal genitalia; internal seminal vesicle 65 (32-65) long, 64 (26-64) wide in posterior portion, oval to spherical; prostatic bulb 51 (38-51) long, 47 (36-59) wide, swollen; male duct short, uniting with female duct at level of approximately proximal $1 / 3$ to $1 / 2$ of sac; hermaphroditic duct strongly muscular, wide, eversible, as intromittent organ, approximately $1 / 2$ length of hermaphroditic sac, lined with ovoid pads or cells of uncertain function. Genital atrium shallow; genital pore medial, 27 (13-27) anterior to anterior margin of ventral sucker.

Ovary spherical to elongate, 68 (64-86) long, 60 (33-66) wide, 109 (27-203) from posterior margin of ventral sucker, contiguous with testis to 80 (3-80) from anterior margin of testis, anteroventral or ventral to intestinal bifurcation. 
Laurer's canal opening dorsally at level of intestinal bifurcation to level of anterior margin of ventral sucker. True seminal receptacle lacking. Vitellarium a single spherical to elongate mass, 61 (40-65) long, 60 (36-63) wide, 173 (87-173) from posterior margin of ventral sucker, dorsal to and contiguous with testis, mostly intercaecal. Uterus occupying most of hindbody, with proximal portion filled with sperm. Eggs in distal portion of uterus 51-52 (44-52) long, 24-26 (20-26) wide, containing developed miracidia having 2 separate to fused eyespots; 1 specimen with hatched miracidia in hermaphroditic duct.

Excretory vesicle weakly Y-shaped (femur-shaped), extending to approximate level of posterior $2 / 5$ to $1 / 2$ of hindbody, representing approximately $25 \%$ (22-33\%) of BL; pore terminal.

Type and only host: Mugil liza Valenciennes, Lebranche mullet, Mugilidae.

Site: Intestine.

Type locality: Rio de la Plata, Punta Lara, Provincia de

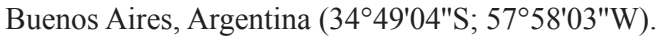

Other locality: Rio Salado, Cerro de la Gloria, Provincia

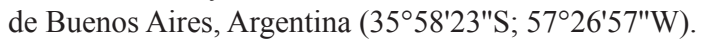

Specimens deposited: Holotype (MACN-Pa 574/1); paratypes MACN-Pa 574/2-574/6, USNM No. 1279848 1279851, and BMNH 2015.3.24.1-2015.3.24.3.

Representative DNA sequences: Partial $18 \mathrm{~S}$ rDNA, entire ITS region, partial (D1-D3) 28S rDNA: GenBank accession no. KP761086, from two identical sequences (two adult specimens one from Rio de la Plata and one from Rio Salado).

E ty m ology: The Latinised name 'platana' refers to the type locality being the Rio de la Plata.

Remarks. Forticulcita platana sp. n. can be distinguished from F. glabra and F. mugilis by being shorter $(<1000 \mu \mathrm{m})$ and possessing a shorter, claviform external seminal vesicle; smaller oral and ventral suckers (both $<100 \mu \mathrm{m})$; and shorter hermaphroditic $\operatorname{sac}(<200 \mu \mathrm{m})$. Additionally, $F$. platana possesses a hermaphroditic duct (or intromittent organ) lined with pads or gland cells. The only other species of Forticulcita in which this feature has been reported is $F$. gibsoni. The new species is morphologically most similar to $F$. gibsoni, but it can be differentiated from that species in possessing a hermaphroditic sac that is one and a half to two times longer than wide rather than approximately three times longer than wide, eggs that are slightly longer (44-52 $\mu \mathrm{m}$ rather than 34-44 $\mu \mathrm{m}$ long), and a shorter post-testicular space $(<45 \%)$.

\section{Forticulcita apiensis sp. n.}

Figs. 4-5

ZooBank number for species:

urn:1sid:zoobank.org:act:AF063E42-BC26-

43CC-BC13-FC0D3EA04B09

Description (based on 9 mature measured wholemounts): Body fusiform, 469 (354-524) long, widest at midbody, 148 (124-153) wide, representing 32\% (28-35\%) of BL. Forebody 132 (124-158) long, representing 28\%
(28-35\%) of BL. Hindbody 258 (157-285) long representing $55 \%(44-55 \%)$ of BL. Eyespot pigment dispersed in forebody to level of approximately $1 / 3$ of BL Tegumental spines thin, 2-4 long, located over entire surface, becoming sparse in posterior $1 / 4$ to posterior $1 / 3$ of body. Oral sucker transversely subspherical, subterminal, 53 (45-67) long, 63 (54-72) wide. Ventral sucker spherical, 79 (73-84) long, 86 (81-87) wide. Ratio of oral sucker to ventral sucker widths $1: 1.37$ ( $1: 1.17-1.44)$. Ratio of oral sucker to ventral sucker lengths $1: 1.49$ (1:1.21-1.62). Prepharynx 16 (9-28) long. Pharynx transversely subglobular, 41 (31-46) long, 47 (42-51) wide. Ratio of oral sucker to pharyngeal widths $1: 0.75$ ( $1: 0.63-0.93)$. Oesophagus 91 (71-121) long, approximately $2-3$ times pharynx length, extending to approximately midbody. Intestinal bifurcation at level of approximately middle to immediately posterior to ventral sucker, dorsal to anterodorsal to hermaphroditic sac. Caeca sac-like, approximately twice as long as wide, vacuolar, terminating blindly at 191 (126-212) from posterior end; postcaecal space representing $41 \%(34-45 \%)$ of BL.

Testis single, subspherical to elongate, 35 (31-53) long, 28 (25-36) wide, contiguous with to 82 from posterior margin of ventral sucker. Posttesticular space 133 (96-186) representing 28\% (27-40\%) of BL. External seminal vesicle claviform, 27 (21-44) long, 14 (12-24) wide, dorsal to ventral sucker, anteriorly directed. Hermaphroditic sac claviform, 99 (84-128) long, 55 (41-55) wide, representing $21 \%(19-30 \%)$ of $\mathrm{BL}$, containing terminal genitalia; internal seminal vesicle, 29 (26-36) long, 28 (20-34) wide in posterior portion, subspherical; prostatic bulb 31 (29-36) long, 33 (24-37) wide, swollen; male duct short, uniting with female duct at approximately posterior $1 / 3$ to midlevel of sac; hermaphroditic duct strongly muscular, eversible, as intromittent organ, sinuous distally in most specimens, approximately $1 / 2$ to $2 / 3$ length of hermaphroditic sac. Genital atrium shallow (4-7); genital pore medial, 12 (8-20) anterior to anterior margin of ventral sucker.

Ovary subspherical to elongate, 31 (27-42) long, 28 $(22-30)$ wide, located at level from approximately middle of ventral sucker to 23 (7-67) from its posterior margin, 42 (7-42) from anterior margin of to contiguous with testis, ventral or posteroventral to intestinal bifurcation, ranging from dextral to sinistral. Laurer's canal pore opening dorsally at level of approximately middle of hindbody. True seminal receptacle lacking. Vitellarium a single subspherical to elongated mass, 31 (28-40) long, 30 (24-32) wide, 59 (20-95) from posterior margin of ventral sucker, dorsal to and contiguous with testis, mostly intercaecal. Uterus occupying most of hindbody, with proximal portion filled with sperm. Eggs in distal portion of uterus, 48-49 (38-49) long, 21-22 (14-20) wide, containing developed miracidia having 2 separate to fused eyespots; 1 specimen (holotype) having hatched miracidia in distal portion of uterus.

Excretory vesicle weakly Y-shaped (femur-shaped) to nearly I-shaped when swollen (in 2 specimens), extending to approximate level of posterior $1 / 3$ to $1 / 2$ of hindbody, representing approximately $19 \%(18-29 \%)$ of $\mathrm{BL}$; pore terminal. 
Type and only host: Mugil cephalus Linnaeus, flathead grey mullet (Mugilidae).

Site: Intestine.

Prevalence: Six of eight infected.

Ty p e lo c a lity: Salt Springs, St. Johns River, Marion County, Florida, USA (29²1'01"N; 81 $\left.{ }^{\circ} 43^{\prime} 57^{\prime \prime} \mathrm{W}\right)$.

Specimens deposited: Holotype, USNM 1279852; paratypes USNM 1279853-1279856, BMNH 2015.3.24.4, 2015.3.24.5

Representative DNA sequences: Partial 18 SrDNA, entire ITS region, partial (D1-D3) 28S rDNA: GenBank accession no. KP761087, of one adult specimen from Salt Springs, Florida, USA.

Etymology: The Latinised feminine name 'apiensis' is derived from 'Api', which is a Native American (north central Florida) word of the Timucuan language for 'salt' alluding to the type locality Salt Spring, Florida, USA.

Remarks. Forticulcita apiensis sp. n. can be differentiated from the other species of Forticulcita based on its overall smaller body length $(<550 \mu \mathrm{m})$ and a testis that is shorter than or equal in length to the pharynx. It is differentiated from $F$. glabra and F. mugilis in possessing a shorter, claviform external seminal vesicle smaller oral and ventral suckers (both $<100 \mu \mathrm{m}$ ) and shorter hermaphroditic sac $(<200 \mu \mathrm{m})$. Forticulcita apiensis can be further differentiated from $F$. gibsoni in possessing a shorter posttesticular space ( $<40 \%$ of body length) and from both $F$. gibsoni and $F$. platana in possessing an ovary that is shorter than the pharynx. Additionally, we did not observe pads or gland cells lining the hermaphroditic duct (or intromittent organ) as in F. platana and F. gibsoni.

\section{Xiha gen. n.}

ZooBank number for genus:

urn:1sid:zoobank.org:act:78DE831D-23C9-

4487-8BF8-A98AC6648AAA

Diagnosis. Body fusiform. Tegument spinous. Eyespot pigment dispersed, mostly in forebody. Oral sucker subspherical, subterminal. Ventral sucker larger than oral sucker. Forebody approximately as long as body width at level of ventral sucker. Prepharynx present. Pharynx well developed. Oesophagus approximately 1 to 6 times longer than pharynx. Caeca saccular, terminating blindly at level of approximate middle of hindbody. Testis elongate. External seminal vesicle present. Hermaphroditic sac elongate, approximately twice as long as ventral sucker, approximately twice as long as female duct. Hermaphroditic duct strongly muscular, lined with spines, likely eversible as intromittent organ. Ovary elongate to subspherical, variably positioned. Vitellarium single mass, elongate to subspherical. Eggs with developed oculate miracidia. Excretory vesicle Y-shaped; pore terminal.

Type species: Xiha fastigata (Thatcher et Sparks, 1958) comb. n. (syn. Dicrogaster fastigatus Thatcher et Sparks, 1952).

Ety mology: The Latinised Native American (northern Gulf of Mexico) 'Xiha' (pronounced CHē'ha) of the Biloxi lan- guage refers to ' $x i$ ' for thorn and 'ha' meaning bearing. The name refers to the spines lining the hermaphroditic duct. We treat the generic name as a feminine noun.

Remarks. Xiha can be differentiated from all other haploporid genera, with the exception of Forticulcita, based on a vitellarium being comprised of a single elongate to subspherical mass rather than one that is transversely elongated and dumbbell-shaped as in Pseudodicrogaster Blasco-Costa, Montero, Gibson, Balbuena et Kostadinova, 2009 or one that consists of two close subpherical masses as in Dicrogaster. Xiha can be easily differentiated from Forticulcita based on possessing a hermaphroditic sac armed with spines

Xiha fastigata (Thatcher et Sparks, 1958) comb. n. Syn. Dicrogaster fastigatus Thatcher et Sparks, 1958

Type host: Mugil cephalus Linnaeus, flathead grey mullet (Mugilidae).

S it e : Intestine.

Type locality: Grand Isle, Louisiana, USA.

Other localities: Rockefeller Wildlife Refuge, Grand Chenier, Louisiana, USA; waters of and adjacent to Mississippi Sound, Mississippi, USA.

Localities of molecular material: Grand Isle, Louisiana, USA $\left(29^{\circ} 14^{\prime} 18^{\prime \prime} \mathrm{N}\right.$; 90 $\left.90^{\circ} 0^{\prime} 13^{\prime \prime} \mathrm{W}\right)$; Davis Bayou,

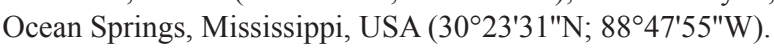
Ho lo ty pe: USNPC 38389.

Supplemental material: USNPC 71961 (Overstreet 1971); USNM 1279857-8 and BMNH 2015.3.24.7 (this study).

Representative DNA sequences: Partial 18SrDNA, entire ITS region, partial (D1-D3) 28S rDNA: GenBank accession no. KP761088, from four identical sequences (two adult specimens from Grand Isle, LA, USA, and two adult specimens from Davis Bayou, Ocean Springs, MS, USA.).

Remarks. Fernández Bargiela (1987) described specimens reported to be $D$. fastigata from $M$. cephalus off Arica and Concepción, Chile, and she described D. fragilis from the same host off Concepción. She considered D. fragilis to be separate from D. fastigata based on having a thin, fragile tegument that is mostly devoid of spines; a smaller oral sucker, ventral sucker and pharynx; and a larger ovary, testis and hermaphroditic sac. Blasco-Costa et al. (2009c) considered $D$. fragilis to be a junior subjective synonym of $D$. fastigata because the morphometrics of $D$. fragilis were within the range of those reported for D. fastigata. Although we have not examined specimens of either of the purported Chilean taxa reported by Fernández Bargiela (1987), we agree with Blasco-Costa et al. (2009c) that they are conspecific. However, we do not agree that the Chilean specimens are conspecific with those from the Gulf of Mexico and off the southeastern USA. Based on our studies of other haploporids, the reported tegumental difference is likely related to fixation technique or because the specimens of $D$. fragilis might have been dead or moribund when removed from the host. Moreover, based on our studies of several published and unpublished New World hap- 


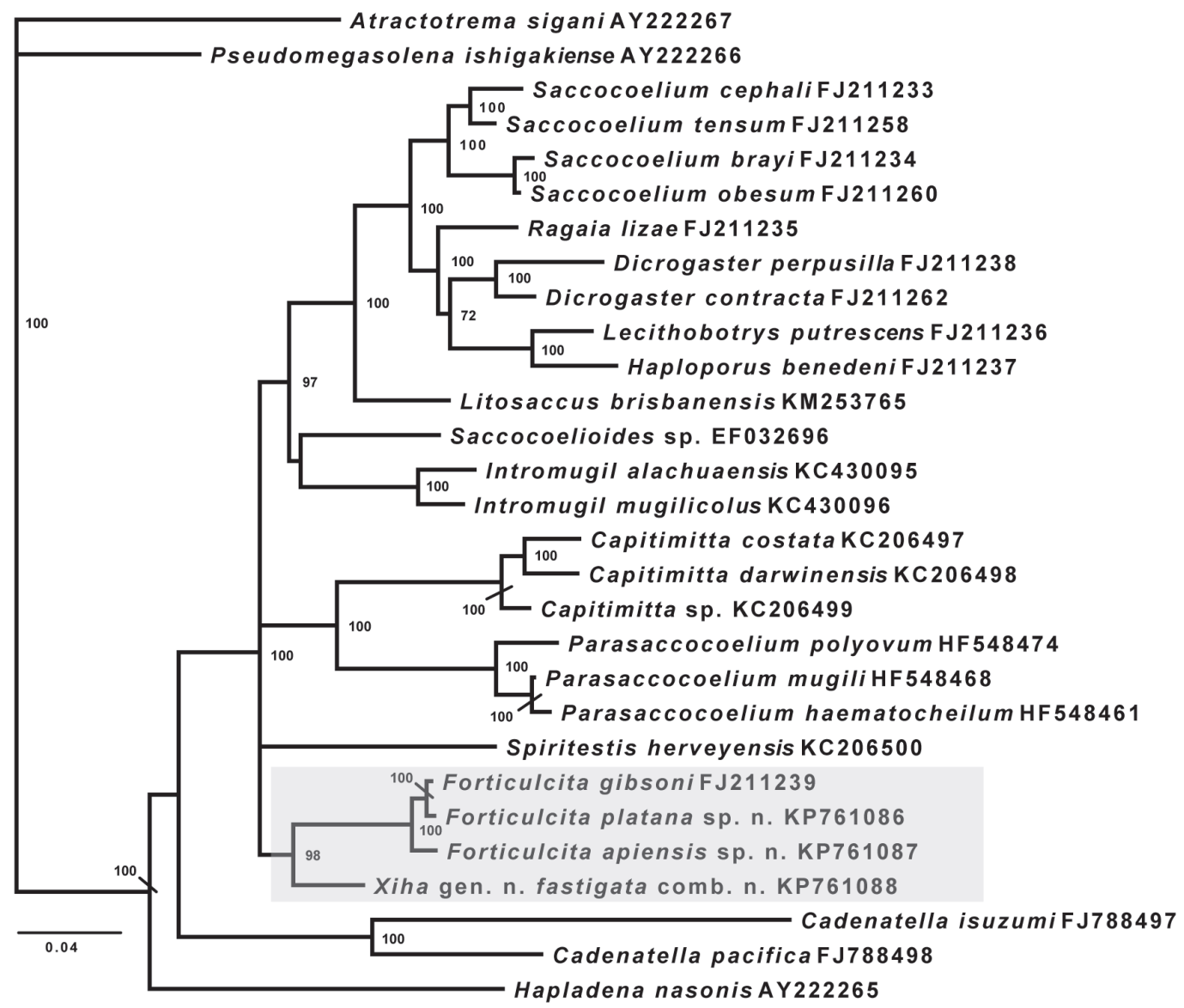

Fig. 6. Phylogenetic relationships among members of the Haploporidae resulting from Bayesian inference analysis of partial $28 \mathrm{~S}$ rDNA sequences (GTR + I + Г, 1000000 generations and a sample frequency of 100) revealing a monophyletic Forticulcitinae (shaded rectangle), with Xiha gen. n. fastigata comb n. as the sister to Forticulcita. Support values of $<70$ not shown.

loporids, we are highly skeptical that Xiha fastigata occurs along the Pacific coast of the New World. The increased use of molecular techniques has revealed a large number of cryptic helminth species (e.g. Blasco-Costa et al. 2010, Pérez-Ponce de León and Nadler 2010, Poulin 2011), and we think that the specimens described by Fernández Bargiela (1987) likely represent a distinct species. Because of our unsuccessful attempts to obtain the specimens and the brevity of the descriptions, additional specimens from the Pacific coast of the New World are needed, preferably coupled with molecular data. Until then, we consider the Chilean material to represent Xiha fragilis (Fernández Bargiela, 1987) comb. n. Dicrogaster fastigata was reported by Knoff et al. (1997) in an ecological study of parasites from $M$. liza (as M. platanus Günther) off Rio de Janeiro, Brazil. They did not deposit any voucher material nor offer any descriptive information on the species, and that specific identification needs confirmation.

\section{Molecular analysis}

The DNA sequence fragments for the two new species of Forticulcita and for Xiha fastigata encompassed a portion of the 3' end of the $18 \mathrm{~S}$ rDNA, the ITS1, $157 \mathrm{bp}$ of the $5.8 \mathrm{~S}$, the ITS2, and $1387 \mathrm{bp}$ of the 5 ' end of the $28 \mathrm{~S}$ rDNA. The sequence lengths for the ITS1 and ITS2 of Forticulcita platana were $599 \mathrm{bp}$ and $275 \mathrm{bp}$, respectively; for $F$. api- ensis were $600 \mathrm{bp}$ and $271 \mathrm{bp}$, respectively; and for $X$. fastigata were $904 \mathrm{bp}$ and 279, respectively. No intraspecific variation was observed when sequences were obtained from multiple specimens. The ITS1 sequence of $F$. platana exhibits $96.2 \%$ similarity to (23 bp different from) the ITS1 sequence of $F$. apiensis. The ITS1 sequence of $X$. fastigata is $304 \mathrm{bp}$ longer than that of $F$. platana and $305 \mathrm{bp}$ longer than that of $F$. apiensis. Pairwise comparison of the ITS2 and partial 28S rDNA of F. gibsoni (FJ211262) and the three other new world forticulcitines are reported in Table 1. Intergeneric divergence between the three species of Forticulcita and $X$. fastigata in the ITS2 and 28S rDNA was $12.9-16.5 \%$ and $5.1-5.2 \%$, respectively.

The sequence alignment included two atractotrematids, two species of Cadenatella Dollfus, 1946 and 25 haploporids, and it was 1128 characters long with 663 conserved sites, 465 variable sites and 335 informative sites. The BI analysis of partial $28 \mathrm{~S}$ rDNA sequences used the atractotrematid $A$. sigani as the outgroup based on its phylogenetic position within the Haploporoidea (see Olson et al. 2003, Andres et al. 2014) (Fig. 6). The Haploporidae was revealed as paraphyletic, similar to that shown in previous analyses (Bray et al. 2014, Andres et al. 2014), with Hapladena nasonis Yamaguti, 1970 basal to Cadenatella and the rest of the Haploporidae. The 22 other non-Hapladena haploporids formed a polytomy consisting of the Forticul- 
citinae, Spiritestis herveyensis Pulis et Overstreet, 2013, Capitimitta spp. + Parasaccocoelium spp., and a clade that included two subclades: one comprised of Intromugil spp. and Saccocoelioides sp., and the other of the Haploporinae. The Forticulcitinae was well supported with $X$. fastigata as sister to the three species of Forticulcita.

\section{DISCUSSION}

Prior to the present study, Forticulcita contained three species: F. glabra (type species), and F. mugilis from the Red Sea (Overstreet 1982, Hassanine 2007) and F. gibsoni from the Mediterranean Sea (Blasco-Costa et al. 2009a). The two new species expand the geographic range of the genus to the New World and into freshwater. The three members of Forticulcita that have representative DNA sequences are morphologically similar to each other, and they differ from both Red Sea species by having a smaller body length $(\mathrm{BL}<1050 \mu \mathrm{m})$, a subspherical rather than triangular to irregular vitellarium, a subspherical rather than an elongate internal seminal vesicle, and a clavate rather than an elongate external seminal vesicle. Even though we consider the two New World species in Forticulcita, we are skeptical that the above characteristics are of specific value and believe that once molecular data become available for $F$. glabra, a new genus may be needed to accommodate $F$. gibsoni, F. platana and F. apiensis. Additionally, Overstreet's (1982) specimens of F. glabra were fixed under slight coverslip pressure and, after examination of four paratypes and photomicrographs of the holotype (USNPC 76518), we were unable to determine the shape of the excretory vesicle. Hassanine (2007) reported the excretory vesicle of F. mugilis as I-shaped, Blasco-Costa et al. (2009a) reported that the excretory vesicle of $F$. gibsoni has a 'bifurcation at mid-hindbody', and the subfamily diagnosis by Blasco-Costa et al (2009b) mentions a Y-shaped excretory vesicle. Based on our observation of the excretory vesicle of $F$. apiensis, we consider the excretory vesicle within Forticulcita to be either I- to weakly Y-shaped.

We erected Xiha to accommodate $X$. fastigata and $X$. fragilis based on the possession of a single compact elongate to subspherical vitellarium, spines lining the hermaphroditic duct and our BI analysis. Yamaguti (1958) was the first to recognise that a single compact vitellarium could be an important subfamilial character when he erected the Dicrogasterinae. However, because Dicrogaster perpusilla has two closely situated masses, Overstreet (1982) did not accept the subfamily and considered Dicrogaster a haploporine, which Blasco-Costa et al. (2009b) demonstrated in their molecular analysis. We agree with Blasco-Costa et al.'s (2009c) erection of Pseudodicrogaster for Dicrogaster japonica Machida, 1996 and agree that it is best placed in the Haploporinae. Pseudodicrogaster japonica (Machida, 1996) has a vitellarium that is a compact, transversely elongated, dumbbell-shaped mass rather than the single subspherical to irregular mass present in members of the Forticulcitinae. We consider the vitellarium being in a single grouping rather than paired (i.e., dumbbell-shaped) to be an important character for the Forticulcitinae. Thus, Dicrogaster currently contains only
D. perpusilla and D. contracta and the generic diagnosis by Overstreet and Curran (2005) necessitates the amendment of eyespot pigment being diffuse but concentrated around the pharynx; oesophagus being equal in size to approximately twice length of pharynx; testis in hindbody, median; and vitelline follicles being coalesced, forming two closely situated masses adjacent to ovary. The addition of these New World species to the Forticulcitinae necessities an amended subfamily diagnosis to that originally provided by Blasco-Costa et al. (2009b). The diagnosis should now include eyespot pigment dispersed between levels of oral sucker and mid-hermaphroditic sac; external seminal vesicle clavate to elongate; hermaphroditic sac elongate, kidney bean-shaped to subcylindrical; hermaphroditic duct eversible, as intromittent organ, lined with spines or not; ovary pretesticular, contiguous with to separated from testis; excretory vesicle I- to weakly Y-shaped.

The BI analysis presented by Blasco-Costa et al. (2009b) estimated the placement of the Forticulcitinae (based on F. gibsoni) as basal to Saccocoelioides sp., but our BI analysis could not resolve the placement of the subfamily relative to the other non-megasolenine haploporid subfamilies. The topology of the BI tree is almost identical to the one presented by Andres et al. (2014), as the topology was mostly unresolved and that relationships could be established among closely related species or genera only. The only meaningful difference between the two, being the slightly lower support for the Saccocoelioides sp. + Intromugil spp. clade and the slightly higher support for the relationship of that clade with the Haploporinae. Xiha fastigata was recovered as the sister to Forticulcita, with $F$. apiensis as the basal member of that genus; therefore, our phylogeny suggests that the Forticulcitinae may have a New World origin.

Surprisingly, $F$. platana is genetically closer to $F$. gibsoni than it is to the other New World species, F. apiensis (Table 1, Fig. 5). One possible explanation is the isolation of F.apiensis within a freshwater spring system. Although there is the possibility that $F$. apiensis was acquired in estuarine waters and carried with its host to the freshwater spring, we believe that $F$. apiensis was acquired in the spring. The hosts from which specimens of $F$. apiensis were isolated were collected at Salt Springs, Florida, approximately $120 \mathrm{~km}$ from the mouth of the St. John's River. Additionally, the specific conductance (an indirect measure of salinity) at Salt Springs is higher than that of the rest of the St. John's River, with the exception of coastal and estuarine locations (Scott et al. 2004, St. Johns River Water Management District 2013). The extensive spring systems across the limestone 'dome' of the Florida peninsula provide important habitats for rich biological communities, including obligate spring taxa (Nordlie 1990, Walsh 2001) and marine and estuarine species (Odom 1953, Walsh 2001, Smock et al. 2005). Odum (1953) surveyed the inland distribution of marine organisms on the peninsula of Florida and related their distribution to the relatively high freshwater chlorinity derived from relic salt deposits in the marine limestone of the Floridian aquifer system. In particular, he found that the St. John's River system had 
Table 2. Pairwise comparisons of percent nucleotide similarity and number of base pair differences (in parentheses) for the ITS-2 (below the diagonal) and 28S rDNA (above the diagonal) of the three species of Forticulcita and Xiha fastigata comb. n.

\begin{tabular}{lcccc}
\hline & Forticulcita gibsoni & Forticulcita platana sp. n. & Forticulcita apiensis sp. n. & Xiha gen. n. fastigata \\
\hline Forticulcita gibsoni & - & $99.6(5)$ & $98.7(16)$ & $94.9(61)$ \\
Forticulcita platana sp. $\mathrm{n}$. & $98.5(4)$ & - & $98.6(17)$ & $94.8(62)$ \\
Forticulcita apiensis sp. $\mathrm{n}$. & $93.7(17)$ & $94.5(15)$ & - & $94.9(61)$ \\
Xiha gen. n. fastigata & $87.1(35)$ & $83.5(45)$ & $85.1(40)$ & - \\
\hline
\end{tabular}

the most extensive 'marine invasions' because of the numerous ionic springs that feed into it. The ionic composition of these springs has allowed for the establishment of patches of estuarine species far removed from the mouth of the river (Smock et al. 2005). Finally, during May 2009, MJA examined eight specimens of $M$. cephalus from Trout River, FL (30²4'13"N; 81 $\left.39^{\circ} 50^{\prime \prime} \mathrm{W}\right)$, near the mouth of the St. John's River, but he found no forticulcitine species. However, additional specimens of $M$. cephalus from other springs and the lower reaches of the St. John's River, along with potential intermediate hosts from Salt Springs, need to be examined to confirm that $F$. apiensis is a spring-associated species. Pulis et al. (2013) suggested a similar pattern of infection for Intromugil alachuaensis (Shireman, 1964) collected from the Santa Fe River, Florida.

Although isolation of $F$. apiensis in freshwater may explain the slightly larger genetic distance between it and the other two species of Forticulcita, the isolation does not help explain the low genetic distance observed between F. gibsoni and F. platana (Table 2, Fig. 6). The high genetic similarity between the two species separated by the Atlantic Ocean is surprising, especially considering they are genetically closer to each other than any of the Mediterranean haploporine species are to one another. Of the haploporine species, Saccocoelium brayi Blasco-Costa, Balbuena, Raga, Kostadinova et Olson, 2010 and S. obesum Looss, 1902 are the two most closely related (97.5\% similarity in the ITS 2 and $99.2 \%$ similarity in the $28 \mathrm{~S}$ rDNA), which is slightly less than what we found for F. gibsoni and $F$. platana (Table 2). The close genetic similarity between $F$. gibsoni and F. platana may suggest that Forticulcita was established in the Mediterranean Sea from the New World relatively recently. One such mechanism for the radiation of Forticulcita in the Mediterranean Sea could have been accomplished by rafting (e.g. Thiel and Haye 2006). The dispersal of a haploporid by aquatic vegetation rafts could have been achieved by the first intermediate host being carried out on the raft, by the final host using the raft for shelter over the open ocean, or by as the second intermediate host itself since haploporid cercariae typically encyst on aquatic vegetation. Collection of potential hosts from the west coast of Africa and the Atlantic volcanic islands, such as the Cape Verde Islands, Ascension Island and St. Helena, may help discern if additional closely related species of Forticulcita occur there and if rafting is a viable explanation. Clearly, molecular data from additional species of Forticulcita, in particular the type-species, F. glabra, are needed to help understand the pattern of radiation within the subfamily.

Acknowledgements. From the University of Southern Mississippi we thank Ronnie Palmer for collecting and preparing the specimen of $F$. gibsoni, Jean Jovonovich Alvillar and Dr Janet Wright for their assistance with DNA sequencing reactions, and Dr Richard Heard for the provision of microscopy and sampling equipment. We thank Pat Pilitt and Dr Eric Hoberg, USNPC, for providing photomicrographs of $F$. glabra and accession numbers; and Eileen Harris, BMNH, for loaning paratypes of $F$. gibsoni and providing accession numbers. We are grateful for the Florida Fish and Wildlife Conservation Commission for issuing the permit FNW-13-05(renewal) that allowed for the collection of fish from springs of Florida. The material treated here is based on work supported by the National Science Foundation under grant no. 0529684 , Ocean and Human Health Initiative grant no. NA08NOS4730322, BP Exploration \& Production Inc., and US Fish and Wildlife Service/Mississippi Department of Marine Resources MSCIAP MS.R.798 Award M10AF20151.

\section{REFERENCES}

Andres M.J., Pulis E.E., Cribb T.H., Overstreet R.M. 2014 Erection of a new haploporine genus and its phylogenetic relationship within the Haploporinae Nicoll, 1914. Syst. Parasitol. 89: 185-194.

Besprozvannykh V.V., Atopkin D.M., Ermolenko A.V., NiKitenko A. 2015: Restoration of the genus Parasaccocoelium Zhukov, 1971 (Digenea: Haploporidae) and a description of two new species from mugilid fish in the Far East of Russia. J. Helminthology: (In press).

Blasco-Costa I., Balbuena J.A., Kostadinova A., Olson P.D. 2009b: Interrelationships of the Haploporinae (Digenea: Haploporidae): a molecular test of the taxonomic framework based on morphology. Parasitol. Int. 58: 263-269.

Blasco-Costa I., Balbuena J.A., Raga J.A., Kostadinova A., OLson P.D. 2010: Molecules and morphology reveal cryptic variation among digeneans infecting sympatric mullets in the Mediterranean. Parasitology 137: 287-302.

Blasco-Costa I., Montero F.E., Balbuena J.A., Raga J.A., Kostadinova A. 2009a: A revision of the Haploporinae Nicoll, 1914 (Digenea: Haploporidae) from mullets (Mugilidae): Dicrogaster Looss, 1902 and Forticulcita Overstreet, 1982. Syst. Parasitol. 72: 187-206.

Blasco-Costa I., Montero F.E., Gibson D.I., Balbuena J.A., Kostadinova A. 2009c: A revision of the Haploporinae Nicoll, 1914 (Digenea: Haploporidae) from mullets (Mugilidae): two new haploporine genera and a key to the genera of the subfamily. Syst. Parasitol. 72: 207-215.

Bray R.A., Cribb T.H., Waeschenbach A., Littlewood D.T.J. 2014: Molecular evidence that the genus Cadenatella Dollfus, 1946 (Digenea; Plagiorchiida) belongs in the superfamily Haploporoidea Nicoll, 1914. Syst. Parasitol. 89: 15-21. 
Bray R.A., Waeschenbach A., Cribb T.H., Weedall G.D., Dyal P., Littlewood D.T.J. 2009: The phylogeny of the Lepocreadiidae (Platyhelminthes: Digenea) inferred from nuclear and mitochondrial genes: implications for their systematics and evolution. Acta Parasitol. 54: 310-329.

Cribb T.H., Bray R.A. 2010: Gut wash, body soak, blender and heat-fixation: approaches to effective collection, fixation and preservation of trematodes of fishes. Syst. Parasitol. 76: 1-7.

Curran S.S., TKach V.V., Overstreet R.M. 2006: A review of Polylekithum Arnold, 1934 and its familial affinities using morphological and molecular data, with description of Polylekithum catahoulensis sp. nov. Acta Parasitol. 51: 238-248.

Fernández Bargiela J. 1987: Los parasitos de la lisa Mugil cephalus L., en Chile: sistematica y aspectos poblacionales (Perciformes: Mugilidae). Gayana Zool. 51: 3-58.

Darriba D., Taboada G.L., Doallo R., Posada D. 2012: jModelTest 2: more models, new heuristics and parallel computing. Nat. Methods 9: 772.

Guindon S., Gascuel O. 2003: A simple, fast, and accurate algorithm to estimate large phylogenies by maximum likelihood. Syst. Biol. 52: 696-704.

HALL T.A. 1999: BioEdit: a user-friendly biological sequence alignment editor and analysis program for Windows 95/98/NT. Nucl. Acids Res. 41: 95-98.

Hassanine R.M.El.-S. 2007: Trematodes from Red Sea fishes: Prosteganoderma brayi gen. nov., sp. nov. (Zoogonidae Odhner, 1902) and Forticulcita mugilis sp. nov. (Haploporidae Nicoll, 1914). Helminthologia 44: 183-187.

Huelsenbeck J.P., Ronquist F. 2001: MRBAYES: Bayesian inference of phylogeny. Bioinformatics 17: 754-755.

Huelsenbeck J.P., Ronquist F., Nielsen R., Bollback J.P. 2001: Bayesian inference of phylogeny and its impact on evolutionary biology. Science 294: 2310-2314.

Katoh K., Kuma K.-I., Toh H., Miyata T. 2005: MAFFT version 5: improvement in accuracy of multiple sequence alignment. Nucl. Acids Res. 33: 511-518.

Knoff M., Luque J.L., Аmato J.F.R. 1997: Community ecology of the metazoan parasites of grey mullets, Mugil platanus (Osteichthyes: Mugilidae) from the littoral of the state of Rio de Janeiro, Brazil. Rev. Bras. Biol. 57: 441-454.

Nordlie F.G. 1990: Rivers and springs. In: R.L. Myers and J.J. Ewel (Eds.), Ecosystems of Florida. University of Central Florida Press, Orlando, FL, pp. 392-426.

Odum H.T. 1953: Factors controlling marine invasion into Florida fresh waters. Bull. Mar. Sci. 3: 134-156.

Olson P.D., Cribi T.H., Tkach V.V., Bray R.A., Littlewood D.T.J. 2003: Phylogeny and classification of the Digenea (Platyhelminthes: Trematoda). Int. J. Parasitol. 33: 733-755.

Overstreet R.M. 1971: Some adult digenetic trematodes in striped mullet from the northern Gulf of Mexico. J. Parasitol. 57: 967-974.
Overstreet R.M. 1982: Forticulcita glabra gen. et sp. n. (Digenea, Haploporidae) in a Red Sea mullet. Zool. Scr. 11: 83-85.

Overstreet R.M., Curran S.S. 2005: Family Haploporidae Nicoll, 1914. In: A. Jones, R.A. Bray and D.I. Gibson (Eds.), Keys to the Trematoda. Volume 2. CABI Publishing and the Natural History Museum, London, pp. 129-165.

Pérez-Ponce de León G., Nadler S.A. 2010: What we don't recognize can hurt us: a plea for awareness about cryptic species. J. Parasitol. 96: 453-464.

Poulin R. 2011: Uneven distribution of cryptic diversity among higher taxa of parasitic worms. Biol. Let. 7: 241-244.

Pulis E.E., Fayton T.J., Curran S.S., Overstreet R.M. 2013: A new species of Intromugil (Digenea: Haploporidae) and redescription of Intromugil mugilicolus. J. Parasitol. 99: 501-508.

Pulis E.E., Overstreet R.M. 2013: Review of haploporid (Trematoda) genera with ornate muscularisation in the region of the oral sucker, including four new species and a new genus. Syst. Parasitol. 84: 167-191.

Scott T.M., Means G.H., Meegan R.P., Means R.C., UpChurch S.B., Copeland R.E., Jones J., Roberts T., Willet A. 2004: Springs of Florida. Florida Geological Survey Bulletin 66, pp. 237-239.

Smock L.A., Wright A.B., Benke A.C. 2005: Atlantic coast rivers of the Southeastern United States. In: A.C. Benke and C.E. Cushing (Eds.), Rivers of North America. Elsevier Academic Press, Burlington, MA, pp. 73-124.

St. Johns River Water Management District 2013: 2012 Water Quality Status and Trends. http://floridaswater.com/hydrologicdata/waterquality/pdfs/specificconductance_map.pdf $10 / 14$.

Thiel M., Haye P.A. 2006: The ecology of rafting in the marine environment. III. Biogeographical and evolutionary consequences. In: R.N. Gibson, R.J.A. Atkinson, and J.D.M. Gordon (Eds.), Oceanography and Marine Biology: An Annual Review. Volume 44. CRC Press, London, pp. 323-429.

Tкасh V.V., Littlewood D.T.J., Olson P.D., Kinsella J.N., Swiderski Z. 2003: Molecular phylogenetic analysis of the Microphalloidea Ward, 1901 (Trematoda: Digenea). Syst. Parasitol. 56: $1-15$.

WALSH S.J. 2001: Freshwater macrofauna of Florida karst habitats. In: E. Kuniansky (Ed.) U.S. Geological Survey Karst Interest Group Proceedings, St. Petersburg, Florida. USGS Water-Resources Investigations Report 01-4011, pp. 78-88.

Yamaguti S. 1958: Systema Helminthum. The Digenetic Trematodes of Vertebrates. Parts I and II. Interscience Publishers, New York, $979+1575 \mathrm{pp}$.

Wu M., Chatterji S., EISEn J.A. 2012: Accounting for alignment uncertainty in phylogenomics. PLOS ONE 7: e30288. 